\title{
Glycaemic Control, Lipid Profile, Blood Pressure and Body Weight Status Among Diabetics in Rural Malaysia
}

Hazizi ASa , Zaitun Ya, Kandiah $\mathrm{M}^{\mathrm{a}}$ and Chan SPb

${ }^{a}$ Department of Nutrition and Dietetics, Universiti Putra Malaysia, Malaysia.

${ }^{b}$ University of Malaya Medical Centre, Kuala Lumpur Malaysia.

\begin{abstract}
Introduction: Diabetes is associated with a high risk of cardiovascular disease. The management of blood glucose, dyslipidaemia and other modifiable risk factor, is a key element in the multifactorial approach to prevent complications of type 2 diabetes. Materials and Methods: A cross sectional study was conducted to determine the level of glycaemic control, lipid profile, blood pressure and body weight status among type 2 diabetics in rural Malaysia. A total of 237 diabetic subjects participated in this study. Physical examination was carried out, including measurements of height, weight, waist and hip circumferences, and systolic and diastolic blood pressure. Fasting venous blood samples were collected to determine the glucose level and lipid profile. Results: About 70\% of the subjects had a high body mass index (BMI), equal to or above $25 \mathrm{~kg} /$ $\mathrm{m} 2$. More than $60 \%$ of the subjects had systolic blood pressure $\geq 140 \mathrm{mmHg}$ and/or diastolic $\geq 90 \mathrm{mmHg}$. Mean fasting blood glucose was $9.84 \pm 4.54 \mathrm{mmol} / \mathrm{L}$. Mean total cholesterol was $5.18 \pm 1.35 \mathrm{mmol} / \mathrm{L}$. High density lipoprotein cholesterol (HDLC) and triglyceride (TG) and glucose levels were higher in male than in female, but not statistically significant ( $p>0.05)$. However, low density lipoprotein cholesterol (LDLC) was higher in females than males $(p<0.05)$. Mean HDLC was below $1.0 \mathrm{mmol} / \mathrm{L}$ in all subjects. Conclusion: Glycaemic control, lipid profile, blood pressure and body weight status were not satisfactory and may increase the risk of microvascular and macrovascular complications among these subjects. Appropriate intervention programs should be implemented for better diabetes control among rural subjects.
\end{abstract}

KEYWORDS: Diabetic control, Diabetes, Rural, Malaysia

\section{INTRODUCTION}

Diabetes mellitus in Malaysia has increased in prevalence since 1960. In 1960, the prevalence of diabetes was $0.6 \%$ of the population, in $1982,2.1 \%$, in $1986,6.3 \%$, and in 1996 , it had risen to $8.3 \% .{ }^{1}$ The prevalence is highest among Indians (3.5\% to $16 \%$ ), followed by Chinese and Malays. ${ }^{2}$ Among Malays in Malaysia, the prevalence is highest among urban Malays $(8.2 \%)$, followed by settlers $(6.7 \%)$ and Malays in rural areas $(2.8 \%) .^{3}$

Diabetes is associated with a high risk of cardiovascular disease (CVD). The management of diabetic dyslipidaemia, a well recognised and modifiable risk factor, is a key element in the multifactorial approach to prevent CVD in individuals with type 2 diabetes. ${ }^{4}$ Tight control of blood glucose and blood pressure has been shown in the United Kingdom Prospective Diabetes Study (UKPDS) to reduce the risk of developing macrovascular and microvascular complications in diabetes mellitus type 2 patients. ${ }^{5}$ Therefore, the

Corresponding author;

Dr. Hazizi Abu Saad

Department of Nutrition and Dietetics

Faculty of Medicine and Health Sciences

Universiti Putra Malaysia

Email: hazizi@medic.upm.edu.my only course for diabetics at present is to ensure perfect control of the status of their diabetes so that the complications may be prevented or delayed.

The American Diabetes Association in its Position Statement, has recommended that patients with diabetes should maintain a systolic blood pressure of $<130 \mathrm{mmHg}$ and a diastolic blood pressure of $<80$ $\mathrm{mmHg} .6,7 \mathrm{In}$ addition, the primary goals of therapy for an adult should be to maintain low density lipoprotein cholesterol (LDLC) below $2.6 \mathrm{mmol} / \mathrm{L}$ and triglycerides (TG) below $1.7 \mathrm{mmol} / \mathrm{L}$, while raising high density lipoprotein cholesterol (HDLC) above $1.15 \mathrm{mmol} / \mathrm{L}$ for men and possibly another $10 \mathrm{mg} / \mathrm{dl}$ higher still for women. ${ }^{6}$

The Asia Pacific Type 2 Diabetes Policy Group, supported by the International Diabetes Foundation (IDF) Western Pacific (WP) Region, has produced the fourth edition of Type 2 Diabetes Practical Targets and Treatments. In the report, the IDF has recommended that patients with diabetes maintain their systolic blood pressure below $130 \mathrm{mmHg}$ and diastolic blood pressure below $80 \mathrm{mmHg}$; total cholesterol should be lower than $4.5 \mathrm{mmol} / \mathrm{L}$, with $\mathrm{LDL}$ cholesterol lower than $2.5 \mathrm{mmol} / \mathrm{L}$. TG should be below $1.5 \mathrm{mmol} / \mathrm{L}$, $\mathrm{HDL}$ cholesterol should exceed $1.0 \mathrm{mmol} / \mathrm{L}$ and fasting glucose should be maintained between 4.4 and $6.1 \mathrm{mmol} / \mathrm{L} .8$ 
The combination of hyperglycaemia, obesity, dyslipidaemia and hypertension has been labelled metabolic syndrome, dysmetabolic syndrome or insulin resistance syndrome. This combination indicates common underlying aetiological factors; it is not surprising that the clinical importance of metabolic syndrome is the high cardiovascular risk associated with it. ${ }^{8}$ Sustained improvement in health is recognised as an important goal in diabetes care. ${ }^{9}$

As Malaysia proceeds rapidly towards a developed economy status, the population's lifestyle will continue to change. The escalation of nutrition-related chronic degenerative diseases, once an urban phenomenon, has now spread to the rural population at an alarming rate. ${ }^{10}$ Therefore, the objective of this study was to determine the level of glycaemic control, lipid profile, blood pressure and body weight status among subjects with type 2 diabetes mellitus, specifically at Felda Gugusan Palong, Gemas Negeri Sembilan, Malaysia.

\section{MATERIALS AND METHODS}

A cross-sectional study was conducted at Felda Gugusan Palong, Gemas Negeri Sembilan. Subjects were selected using cluster sampling, wherein 1184 settlers were sampled and a total of 237 diabetic subjects were recruited for this study. Informed consent was obtained and:

1. Subjects were interviewed using pre-tested questionnaires.

2. Subjects were examined to determine height, weight, waist and hip circumferences, and systolic and diastolic blood pressure.

Inclusion criteria included selected settlers (husband and wife) identified in the sampling frame and their agreement to participate in this study, attend blood collection centres and be interviewed during data collection. Exclusion criteria included subjects with mental disorders, AIDS or HIV positive status.

Sample size calculation

The formula used for calculating sample size was: $\mathrm{n}$ $=Z(1-\alpha / 2)^{2} \times p \times(1-p) / d^{2}$, where $Z(1-\alpha / 2)$ indicates $95 \%$ confidence level, $p$ is the prevalence of FPG $<6.1 \mathrm{mmol} / \mathrm{L} /$ good glycaemic control (according to Mafauzy, $18 \%$ ), and $d$ is the desired accuracy level for estimating prevalence of good glycaemic control (set at \pm 0.10 ). ${ }^{11,12}$ Given these parameters, we required a sample size of at least 56 subjects for this study.

Weight was measured with a Tanita digital weighing scale (Japan), and height was measured using a SECA bodymeter (Germany). Each measurement was recorded to the nearest $0.1 \mathrm{~kg}$ and $0.1 \mathrm{~cm}$, respectively. Body mass index (BMI) was computed using the ratio of weight $(\mathrm{kg})$ per height2 $(\mathrm{m} 2)$, and following the classification of the World Health Organization. ${ }^{13}$ Waist and hip circumferences were measured using an inelastic measuring tape to the nearest $0.1 \mathrm{~cm}$.
Waist circumference was obtained by measuring the distance around the smallest area below the rib cage and above the umbilicus and was analysed using the National Institute of Health's classification. ${ }^{14} \mathrm{Hip}$ circumference was measured at the point yielding the maximum circumference over the buttocks with the tape held in a horizontal plane. Blood pressure was measured using Omron digital blood pressure monitor (Japan).

Fasting blood samples were collected to determine glucose levels and lipid profile (TC, HDLC, LDLC and TG). Biochemical analyses were done using the Hitachi Chemical Analyser (Japan). Total LDLC was calculated using Friedewald formula. ${ }^{15}$

Statistical analysis was done using SPSS version 12.0. All the variables were coded, and appropriate statistical analyses were performed, including determining the mean and standard deviation, and utilising the chi square test for association and the t-test for difference. Statistical significance was assessed at a level of less than 0.05 .

The objective of this study was to determine the level of glycaemic control, lipid profile, blood pressure and body weight status among subjects with type 2 diabetes mellitus specifically at Felda Gugusan Palong, Gemas Negeri Sembilan, Malaysia. Data on the glycaemic control, lipid profile, blood pressure and body weight status among type 2 diabetes mellitus, especially in rural Malaysia, are limited. In the present study, we assess the level of glycaemic control, lipid profile, blood pressure and body weight status among subjects with type 2 diabetes mellitus at Felda Gugusan Palong, Gemas Negeri Sembilan, Malaysia.

\section{RESULTS}

\section{Socio-demography}

Table I presents the socio-demographic data of subjects by gender. The study group consisted of 237 subjects, of which $42.6 \%$ were male and $57.4 \%$ were female. The majority of the subjects (91.5\%) were 40-59 years old; $72.2 \%$ of all subjects were Malay and $27.8 \%$ were Indian. About $95 \%$ of the subjects were married, and $5.1 \%$ were widowed or divorced. Only $13.1 \%$ of the subjects had never acquired any formal education, while the majority of the subjects $(75.9 \%)$ had a primary school education. A higher percentage of males had a secondary level of education, and the difference in education level between male and female subjects was statistically significantly $(p<0.05)$. The mean monthly income was RM 656.24 \pm RM 520.41, and while males had a higher monthly income than females, this did not prove to be statistically significant ( $p>0.05$ ). The mean household size was $4.52 \pm 2.09$ and was higher among male subjects $(p<0.05)$.

Table I. Socio-demography data of subjects by gender 


\begin{tabular}{|c|c|c|c|c|c|}
\hline & Male & Fernale & Total & $x^{2}$ & $\begin{array}{c}P \\
\text { value }\end{array}$ \\
\hline $\mathbf{n}$ & $\begin{array}{c}101 \\
(42.6 \% \\
)\end{array}$ & $\begin{array}{c}136 \\
(57.4 \%)\end{array}$ & $\begin{array}{c}237 \\
(100 \%)\end{array}$ & & \\
\hline Age (years) & $\begin{array}{l}52.86 \\
\pm 5.83\end{array}$ & $\begin{array}{c}48.89 \pm \\
5.73\end{array}$ & $\begin{array}{c}50.58 \pm \\
6.09\end{array}$ & & \\
\hline $30-39$ & $3(3.0)$ & $6(4.4)$ & $9(3.8)$ & & $s$ \\
\hline $40-49$ & $\begin{array}{c}25 \\
(24.8)\end{array}$ & $77(56.6)$ & $\begin{array}{c}102 \\
(43.0)\end{array}$ & & \\
\hline 50-59 & $\begin{array}{c}66 \\
(65.3)\end{array}$ & $49(36.0)$ & $\begin{array}{c}115 \\
(48.5)\end{array}$ & & \\
\hline$\geq 60$ & $7(6.9)$ & $4(3.0)$ & $11(4.7)$ & & \\
\hline \multicolumn{6}{|l|}{ Ethnic } \\
\hline Malay & $\begin{array}{c}66 \\
(65.3)\end{array}$ & $\begin{array}{c}105 \\
(77.2)\end{array}$ & $\begin{array}{c}171 \\
(72.2)\end{array}$ & 4.06 & 0.06 \\
\hline Indian & $\begin{array}{c}35 \\
(34.7)\end{array}$ & $31(22.8)$ & $66(27.8)$ & & \\
\hline \multicolumn{6}{|c|}{ Marital status } \\
\hline Married & $\begin{array}{c}100 \\
(99.0)\end{array}$ & $\begin{array}{c}125 \\
(91.9)\end{array}$ & $\begin{array}{c}225 \\
(94.9)\end{array}$ & 6.08 & 0.02 \\
\hline $\begin{array}{l}\text { Widow/ } \\
\text { Widower' } \\
\text { Divorced }\end{array}$ & $1(1.0)$ & $11(8.1)$ & $12(5.1)$ & & \\
\hline \multicolumn{6}{|c|}{ Education level } \\
\hline $\begin{array}{l}\text { No formal } \\
\text { education }\end{array}$ & $8(7.9)$ & $23(16.9)$ & $31(13.1)$ & 6.04 & 0.04 \\
\hline Primary & $\begin{array}{c}78 \\
(77.2)\end{array}$ & $\begin{array}{c}102 \\
(75.0)\end{array}$ & $\begin{array}{c}180 \\
(75.9)\end{array}$ & & \\
\hline Secondary & $\begin{array}{c}15 \\
(14.9)\end{array}$ & $11(8.1)$ & $26(11.0)$ & & \\
\hline \multicolumn{6}{|l|}{ Occupation } \\
\hline $\begin{array}{l}\text { Settlers } \\
\text { Other }\end{array}$ & $\begin{array}{c}95(94 . \\
1) \\
6(5.9)\end{array}$ & $\begin{array}{c}129(94.9 \\
7(5.1)\end{array}$ & $\frac{1}{224(94.5}$ & 0.07 & 0.5 \\
\hline $\begin{array}{l}\text { Monthly } \\
\text { incorne (RM) }\end{array}$ & $\begin{array}{c}753.47 \\
\pm \\
616.66\end{array}$ & $\begin{array}{l}584.04 t \\
423.59\end{array}$ & $\begin{array}{l}656.24 \pm \\
520.41\end{array}$ & 0.67 & 0.5 \\
\hline $\begin{array}{l}\text { Household } \\
\text { size }\end{array}$ & $\begin{array}{c}4.62 t \\
2.28\end{array}$ & $\begin{array}{c}4.44 \pm \\
1.93\end{array}$ & $\begin{array}{c}4.52 \pm \\
2.09\end{array}$ & 2.51 & 0.02 \\
\hline
\end{tabular}

\# Chi squared could not performed because more than $20 \%$ of the cells have expected values less than 5

\section{Anthropometric Measurements}

Table II shows the anthropometric measurements and blood pressure levels by gender. The mean BMI of all subjects was $27.47 \pm 5.00 \mathrm{~kg} / \mathrm{m} 2$, with females possessing a higher BMI $(28.15 \pm 5.60 \mathrm{~kg} / \mathrm{m} 2)$ than males $(26.55 \pm 3.89 \mathrm{~kg} / \mathrm{m} 2 ; p<0.05)$. The difference in height, weight and BMI between males and females was statistically significant $(p<0.05)$. Waist circumference was not significantly different between males and females ( $p>0.05)$. Waist to hip ratio was higher among males than females $(p<0.05)$, but hip circumference showed the opposite trend $(p<0.05)$.

The classifications of body mass index, central obesity and waist to hip ratio of the subjects by gender are presented in Table III. Overall, less than 30\% of the subjects were classified as at a normal BMI, with more males $(37.6 \%)$ than females $(23.5 \%)$ in this category. Furthermore, $47.3 \%$ of subjects were classified as overweight, while $22.4 \%$ were obese. Nearly $63 \%$ of the subjects were classified as having a waist to hip ratio (WHR) $\geq 0.95$ for males or $\geq 0.85$ for females. Based on waist circumference, $18.8 \%$ of males were at high risk of co-morbidities compared to the almost threefold increase of high risk among females (61\%). Gender differences in waist circumference and waist to hip ratio were statistically significant $(p<0.05)$, with a higher percentage of female subjects categorised as having abdominal obesity and at high risk of comorbidity.

\section{Blood pressure}

Table IV presents the blood pressure categories of the subjects by gender. Based on the systolic blood pressure, $46.8 \%$ of the subjects were classified as having a systolic blood pressure $\geq 140 \mathrm{mmHg}$, and $54.4 \%$ of the subjects were identified as having a diastolic blood pressure $\geq 90 \mathrm{mmHg}$. In total, more than $60 \%$ of the subjects were identified as having a systolic blood pressure $\geq 140 \mathrm{mmHg}$ and/or a diastolic blood pressure $\geq 90 \mathrm{mmHg}$. The results of this study showed no gender differences in term of blood pressure classification $(p>0.05)$.

\section{Fasting Blood Glucose and Lipid Profile}

Means \pm standard deviations for lipid profile and for glucose by gender are presented in Table $\mathrm{V}$. Mean total cholesterol for males was $5.04 \pm 1.40 \mathrm{mmol} / \mathrm{L}$ and $5.29 \pm 1.31 \mathrm{mmol} / \mathrm{L}$ for females. HDLC and glucose were higher in males than in females, but the differences were not statistically significant $(p>0.05)$. LDLC was higher in females than males $(p<0.05)$, while triglyceride levels showed an opposite trend.

Results from this study were compared to targeted lipid profiles, blood pressure and BMI for diabetics. The mean for systolic and diastolic blood pressure was above $140 / 90 \mathrm{mmHg}$. The majority of subjects $(64.1 \%)$ had a blood pressure $\geq 140 / 90 \mathrm{mmHg}$, and only $15.2 \%$ had a blood pressure in the optimal range $(<130 / 80 \mathrm{mmHg})$. Fasting blood glucose was at an optimal level for only $14.8 \%$ of the subjects, and a majority of the subjects $(64.1 \%)$ had fasting blood glucose of more than $7.0 \mathrm{mmol} / \mathrm{L}$. Only $24.9 \%$ of the subjects had a total cholesterol $\geq 6.0 \mathrm{mmol} / \mathrm{L}$, while $30.4 \%$ of the subjects were in the optimal range. LDL-cholesterol measurements showed that $39.2 \%$ of subjects had a level $>4.0 \mathrm{mmol} / \mathrm{L}$, while only $15.6 \%$ had an LDLC $<2.5 \mathrm{mmol} / \mathrm{L}$. As for HDL-cholesterol measurements, only $16.5 \%$ of the subjects had HDL-cholesterol levels $>1.1 \mathrm{mmol} / \mathrm{L}$, while $71.3 \%$ had a level $<0.9 \mathrm{mmol} / \mathrm{L}$. For triglycerides, the majority of the subjects $(57.5 \%)$ were at an optimal level, and only $13.5 \%$ of the subjects had triglycerides $>2.2 \mathrm{mmol} / \mathrm{L}$. The majority of the subjects (56.5\%) had a high BMI $(\geq 27 \mathrm{~kg} / \mathrm{m} 2$ for males \& $\geq 26 \mathrm{~kg} / \mathrm{m} 2$ for females), while less than $27 \%$ of the subjects had a BMI in the optimal range. 
Table II. Mean a standard deviation for anthropometric measurements and blood pressure by gender

\begin{tabular}{lrrrrr} 
& Male & Female & Total & p value \\
& $n=101$ & $n=136$ & $n=237$ & & \\
\hline Height (cm) & $164.65 \pm 5.81$ & $150.94 \pm 6.64$ & $156.78 \pm 9.26$ & 16.58 & 0 \\
Weight (kg) & $71.96 \pm 10.89$ & $63.98 \pm 11.87$ & $67.38 \pm 12.10$ & 5.3 & 0 \\
BMI (kg/m²) & $26.55 \pm 3.89$ & $28.15 \pm 5.60$ & $27.47 \pm 5.00$ & -2.47 & 0.01 \\
Diastolic (mmHg) & $91.21 \pm 11.93$ & $92.43 \pm 12.69$ & $91.91 \pm 12.75$ & -0.73 & 0.47 \\
Systolic (mmHg) & $141.80 \pm 24.52$ & $139.29 \pm 20.81$ & $140.36 \pm 2.45$ & 0.83 & 0.4 \\
Waist circumference (cm) & $92.96 \pm 12.90$ & $90.25 \pm 82.26$ & $100.37 \pm 10.41$ & 1.76 & 0.08 \\
Hip circumference (cm) & $97.38 \pm 7.89$ & $102.58 \pm 11.48$ & $91.41 \pm 11.31$ & -3.92 & 0 \\
Waist to Hip Ratio (WHR) & $0.96 \pm 0.11$ & $0.88 \pm 0.08$ & $0.91 \pm 0.10$ & 5.77 & 0
\end{tabular}

Table III. Classification of body mass index, central obesity and waist to hip ratio of the subjects by gender

\begin{tabular}{|c|c|c|c|c|c|c|}
\hline & & $\begin{array}{c}\text { Male } \\
n=101 \\
n(x)\end{array}$ & $\begin{array}{c}\text { Fermale } \\
n=136 \\
n(x)\end{array}$ & $\begin{array}{c}\text { Total } \\
n=237 \\
n(x)\end{array}$ & $x^{2}$ & $\begin{array}{c}P \\
\text { value }\end{array}$ \\
\hline ВMI $\left(\mathrm{kg} / \mathrm{m}^{2}\right)$ & $\begin{array}{l}\text { Underweight }\left(-18.5 \mathrm{~kg} / \mathrm{m}^{2}\right) \\
\text { Normal }\left(18.5-24.9 \mathrm{~kg} / \mathrm{m}^{2}\right) \\
\text { Overweight }\left(25.0-29.9 \mathrm{~kg} / \mathrm{m}^{2}\right) \\
\text { Obese }\left(230 \mathrm{~kg} / \mathrm{m}^{2}\right)\end{array}$ & $\begin{array}{c}0 \\
38(37.6) \\
43(42.6) \\
20(19.8)\end{array}$ & $\begin{array}{c}2(1.5) \\
32(23.5) \\
69(50.7) \\
33(24.3)\end{array}$ & $\begin{array}{c}2(0.8) \\
70(29.5) \\
112(47.3) \\
53(22.4)\end{array}$ & & H \\
\hline Central obesity & $\begin{array}{l}\text { Normal } \\
\text { Android obesity (WHR }=0.95 \delta \\
\text { and WHR } \approx 0.85 \text { ) }\end{array}$ & $\begin{array}{l}48(47.5) \\
53(52.5)\end{array}$ & $\begin{array}{l}40(29.4) \\
96(70.6)\end{array}$ & $\begin{array}{l}88(37.1) \\
149(62.9)\end{array}$ & 8.14 & $\mathbf{0}$ \\
\hline Waist circumference & $\begin{array}{l}\text { Normal }(\bar{\alpha} \leq 102 \mathrm{~cm}, q \leq 88 \mathrm{~cm}) \\
\text { High risk }(\bar{\partial}>102 \mathrm{~cm}, q>88 \mathrm{~cm})\end{array}$ & $\begin{array}{l}82(81.2) \\
19(18.8)\end{array}$ & $\begin{array}{l}53(39.0) \\
83(61.0)\end{array}$ & $\begin{array}{l}135(57.0) \\
102(43.0)\end{array}$ & 42.14 & o \\
\hline Waist circumference ${ }^{*}$ & $\begin{array}{l}\text { Normal }\left(\sigma^{\prime} \leq 90 \mathrm{~cm}, q \leq 80 \mathrm{~cm}\right) \\
\text { High risk }\left(\sigma^{\prime}>90 \mathrm{~cm}, q>80 \mathrm{~cm}\right)\end{array}$ & $\begin{array}{l}35(34.7) \\
66(65.3)\end{array}$ & $\begin{array}{c}18(13.2) \\
118(86.8)\end{array}$ & $\begin{array}{c}53(22.4) \\
184(77.6)\end{array}$ & 15.31 & 0 \\
\hline
\end{tabular}

* According to the Asia-Pacific regional guidelines, abdominal obesity was defined as a WC $>90 \mathrm{~cm}$ for men and $>80 \mathrm{~cm}$ for women.

Source: Steering Committee of the WHO Western Pacific Region, IASO \& IOTF. The Asia-Pacific perspective: Redefining obesity and its treatment. Australia : WHO Western Pacific Region, 2000. 
Table IV. Blood pressure categories by gender

\begin{tabular}{|c|c|c|c|c|c|c|}
\hline & & $\begin{array}{c}\text { Male } \\
n=101 \\
n(\%)\end{array}$ & $\begin{array}{c}\text { Female } \\
n=136 \\
n(x)\end{array}$ & $\begin{array}{c}\text { Total } \\
n=237 \\
n(x)\end{array}$ & $x^{2}$ & p value \\
\hline \multirow[t]{2}{*}{ Systolic blood pressure } & Normal & $54(53.5)$ & $72(52.9)$ & $126(53.2)$ & 0 & 1 \\
\hline & $\geq 140 \mathrm{mmHg}$ & $47(46.5)$ & $64(47.1)$ & $111(46.8)$ & & \\
\hline \multirow[t]{2}{*}{ Diastolic blood pressure } & Normal & $47(46.5)$ & $61(44.9)$ & $108(45.6)$ & 0.07 & 0.9 \\
\hline & $>90 \mathrm{mmHg}$ & $54(53.5)$ & $75(55.1)$ & $129(54.4)$ & & \\
\hline \multirow[t]{2}{*}{ Blood pressure } & Normal & $40(39.6)$ & $52(38.2)$ & $92(38.8)$ & 0.05 & 0.89 \\
\hline & $\begin{array}{l}\text { High blood pressure } \\
\text { (Systotic } \geq 140 \mathrm{mmiHg} \\
\text { and/or diastolic } \geq 90 \\
\text { mmHg.) }\end{array}$ & $61(60.4)$ & $84(61.8)$ & $145(61.2)$ & & \\
\hline
\end{tabular}

Table V. Lipid profile and glucose levels (mean \pm standard deviation) by gender

\begin{tabular}{lccccc} 
& \multicolumn{1}{c}{$\begin{array}{c}\text { Male } \\
\mathrm{n}=101\end{array}$} & $\begin{array}{c}\text { Female } \\
\mathrm{n}=136\end{array}$ & $\begin{array}{c}\text { Total } \\
\mathrm{n}=237\end{array}$ & t & p value \\
\hline Total cholesterol (mmol/L) & $5.04 \pm 1.40$ & $5.29 \pm 1.31$ & $5.18 \pm 1.35$ & -1.14 & 0.16 \\
HDLC (mmol/L) & $0.77 \pm 0.51$ & $0.76 \pm 0.43$ & $0.76 \pm 0.47$ & tu0.19 & 0.85 \\
Triglyceride (mmol/L) & $1.68 \pm 0.95$ & $1.47 \pm 0.72$ & $1.56 \pm 0.83$ & 1.94 & 0.05 \\
LDLC (mmol/L) & $3.51 \pm 1.20$ & $3.87 \pm 1.19$ & $3.71 \pm 1.21$ & -2.29 & 0.02 \\
\hline Glucose level (mmol/L) & $10.37 \pm 5.32$ & $9.44 \pm 3.84$ & $9.84 \pm 4.54$ & 1.57 & 0.12
\end{tabular}

Table VI. Status of lipid profile, glucose level, blood pressure and BMI among the subjects

\begin{tabular}{|c|c|c|c|}
\hline & $\begin{array}{c}\text { Good } \\
x\end{array}$ & $\begin{array}{c}\text { Moderate } \\
x\end{array}$ & $\begin{array}{l}\text { Poor } \\
x\end{array}$ \\
\hline Blood Pressure (mmHg) & $\begin{array}{c}15.2 \\
(<130 / 80 \mathrm{mmHg})\end{array}$ & $\begin{array}{c}20.7 \\
(\geq 130 / 80-<140 / 90 \mathrm{mmHg})\end{array}$ & $\begin{array}{c}64.1 \\
(\geq 140 / 90 \mathrm{mmHg})\end{array}$ \\
\hline Glucose Level ${ }^{*}(\mathrm{mmol} / \mathrm{L})$ & $\begin{array}{c}14.8 \\
\text { (4.4-6.1 mmol/L) }\end{array}$ & $\begin{array}{c}19.8 \\
(6.2-7.0 \mathrm{mmol} / \mathrm{L})\end{array}$ & $\begin{array}{c}64.1 \\
(>7.0 \mathrm{mmol} / \mathrm{L})\end{array}$ \\
\hline Triglyceride (mmol/L) & $\begin{array}{c}57.4 \\
(<1.5 \mathrm{mmol} / \mathrm{L})\end{array}$ & $\begin{array}{c}29.1 \\
(1.5-2.1 \mathrm{mmol} / \mathrm{L})\end{array}$ & $\begin{array}{c}13.5 \\
(\geq 2.2 \mathrm{mmol} / \mathrm{L})\end{array}$ \\
\hline LDLC (mmol/L) & $\begin{array}{c}15.6 \\
(<2.5 \mathrm{mmol} / \mathrm{L})\end{array}$ & $\begin{array}{c}45.2 \\
(2.5-4.0 \mathrm{mmol} / \mathrm{L})\end{array}$ & $\begin{array}{c}39.2 \\
(>4.0 \mathrm{mrnol} / \mathrm{L})\end{array}$ \\
\hline HDLC (mrnol/L) & $\begin{array}{c}16.5 \\
(>1.1 \mathrm{mmol} / \mathrm{L})\end{array}$ & $\begin{array}{c}12.2 \\
(1.1-0.9 \mathrm{mmol} / \mathrm{L})\end{array}$ & $\begin{array}{c}71.3 \\
(\odot 0.9 \mathrm{mmol} / \mathrm{L})\end{array}$ \\
\hline Total Cholesterol (mmol/L) & $\begin{array}{c}30.4 \\
(<4.5 \mathrm{mmol} / \mathrm{L})\end{array}$ & $\begin{array}{c}44.7 \\
(4.5-5.9 \mathrm{mmol} / \mathrm{L})\end{array}$ & $\begin{array}{c}24.9 \\
(\geq 6.0 \mathrm{mmol} / \mathrm{L})\end{array}$ \\
\hline $\begin{array}{l}\text { BMI } \\
\left(\mathrm{kg} / \mathrm{m}^{2}\right)\end{array}$ & $\begin{array}{c}26.2 \\
\left(<25 \mathrm{~kg} / \mathrm{m}^{2} \delta,<24\right. \\
\left.\mathrm{kg} / \mathrm{m}^{2} \phi\right)\end{array}$ & $\begin{array}{c}17.3 \\
\left(25-26.9 \mathrm{~kg} / \mathrm{m}^{2} \delta, 24-25.9\right. \\
\left.\mathrm{kg} / \mathrm{m}^{2} \phi\right)\end{array}$ & $\begin{array}{c}56.5 \\
\left(\geq 27 \mathrm{~kg} / \mathrm{m}^{2} \delta, \geq 26\right. \\
\left.\mathrm{kg} / \mathrm{m}^{2} \phi\right)\end{array}$ \\
\hline
\end{tabular}


* Total less than $100 \%$ because another $1.3 \%$ could not fitted to any categories, their blood glucose was less than $4.4 \mathrm{mmol} / \mathrm{L}$.

\section{DISCUSSION}

The Diabetes Control and Complications Trial (DCCT) and other European studies have demonstrated the efficacy of intensive insulin treatment in preventing the onset and/or progression of microvascular complications such as retinopathy, nephropathy, and neuropathy. ${ }^{16-19}$ The results from this study showed that the majority $(64.1 \%)$ of the subjects have fasting blood glucose levels above $7.0 \mathrm{mmol} / \mathrm{L}$. Other studies in Malaysia showed similar results, where diabetic subjects had fasting blood glucose levels beyond the optimum level. Studies by Eid et al, Suhaiza et al and Mafauzy et al showed $60 \%, 85.7 \%$ and $89 \%$ of their diabetic subjects, respectively, had fasting glucose levels above $6.7 \mathrm{mmol} / \mathrm{L} .{ }^{20-22}$ These figures indicate the urgency of controlling and preventing microvascular complications among diabetics in rural areas. The majority of the subjects in this study would also require intervention and ongoing monitoring to ensure that targeted glucose levels are reached and maintained.

The Action in Diabetes and Vascular Disease: Preterex and Diamicron Modified Release Controlled Evaluation (ADVANCE) showed that an intensive glucose control strategy significantly reduced the primarily composite outcome of major macrovascular events, mainly as a consequence of a reduction in nephropathy. ${ }^{23}$ Other prospective studies have shown continuous associations of blood glucose and glycated haemoglobin levels with the risks of major vascular events. ${ }^{24,25}$

A positive relationship between glycaemic control and the concentration of TC, LDLC and triglycerides has been reported by The Diabetes Control and Complications Trial (DCCT). ${ }^{26}$ The data from The SEARCH diabetes study show that the association between poor diabetes control and high concentration of TC, LDLC and triglycerides also extends to those between 10 and 22 years old in all major ethnic/racial groups. ${ }^{27}$ Similar results were obtained in this study, namely, a positive and significant correlation between fasting blood sugar and TC $(r=0.197 ; p<0.01)$, and between fasting blood sugar and triglycerides $(r=0.391 ; p<0.01)$, but not between fasting blood sugar and LDLC ( $p>0.05)$.

In this study, about one-fourth of the subjects exceeded the targeted level of total cholesterol, and about $40 \%$ of the subjects had LDL cholesterol levels above $4.0 \mathrm{mmol} / \mathrm{L}$. Studies by Mafauzy et al showed that $87.7 \%$ of diabetic subjects had total cholesterol levels above $4.8 \mathrm{mmol} / \mathrm{L}$, while those of Ismail et al found that $73.2 \%$ of their subjects had levels above $5.2 \mathrm{mmol} / \mathrm{L} .22,28$ Results from the present study showed that $39.2 \%$ of the subjects had LDL cholesterol above $4.0 \mathrm{mmol} / \mathrm{L}$. This percentage is lower than that in studies by Eid et al, in which $62 \%$ of their subjects were classified as having high LDLC.20 Studies by Ismail et al found that $90.9 \%$ of diabetics analysed had

\section{LDLC levels above $2.6 \mathrm{mmol} / \mathrm{L}^{28}$}

The NCEP ATP (III) recommends aggressive LDL reduction for patients with diabetes, and the ADA recommends that LDLC be maintained below $2.6 \mathrm{mmol} / \mathrm{L} .6$ This targeted value is achievable, as results of this study showed that only $15.6 \%$ of the subjects had LDLC levels less than $2.5 \mathrm{mmol} / \mathrm{L}$. With regard to HDLC, this study showed that more than $70 \%$ of the subjects had HDLC levels below $0.9 \mathrm{mmol} / \mathrm{L}$, even though they were medicated. Therefore, intervention programs targeted to physical activity are suggested to increase HDLC levels in this community.

The mean systolic and diastolic blood pressure was above $140 / 90 \mathrm{mmHg}$. The majority of the subjects $(64.1 \%)$ had blood pressure measurements $\geq 140 / 90 \mathrm{mmHg}$, and only $15.2 \%$ had blood pressure measurements in the optimum range $(<130 / 80 \mathrm{mmHg})$. Studies by Mafauzy showed that $40.9 \%$ of his subjects had high blood pressure. ${ }^{22}$ Chuang et al reported that, among diabetics in Asia, $27 \%$ had diastolic blood pressure levels above $140 \mathrm{mmHg}$, while $10 \%$ had systolic blood pressure levels above $90 \mathrm{mmHg} .{ }^{29}$ Control of blood pressure is important in preventing cardiovascular complications among diabetics.

Being overweight constitutes a health risk as it is associated with several co-morbidities, including type 2 diabetes mellitus, cardiovascular diseases, hypertension, dyslipidaemia, hyperuricaemia, respiratory diseases, osteo-arthritis and depression. ${ }^{30,31}$ The majority of the subjects in this study (56.5\%) had a BMI at or above $27 \mathrm{~kg} / \mathrm{m} 2$ for males and at or above $26 \mathrm{~kg} /$ $\mathrm{m} 2$ for females. Only $26.9 \%$ of the subjects' BMI measurements were in the optimal range. Similar findings have also been reported by Mafauzy, $81.4 \%$ of their subjects had $\mathrm{BMI}>23 \mathrm{~kg} / \mathrm{m} 2.22$ According to Ford et al, for every kilogram of weight gain, the risk of diabetes increases between $4.5 \%$ and $9 \%{ }^{32}$ The relationship between obesity and diabetes is of such interdependence that the term 'diabesity' has been coined. ${ }^{33}$ According to Kahn et al, in obese individuals, adipose tissue releases increased amounts of non-esterified fatty acids, glycerol, hormones, pro-inflammatory cytokines and other components of insulin resistance. ${ }^{34}$ When insulin resistance is accompanied by dysfunction of pancreatic islet -cells - the cells that release insulin - failure to control blood glucose levels results.

This study has shown similar results to other studies involving diabetics in Malaysia. The prevalence of dyslipidaemia, high blood pressure, obesity and poor glycaemic control (as evidenced by fasting blood glucose levels) are alarming in rural areas and highlight the need for lifestyle intervention programs to control diabetes. 


\section{CONCLUSION}

Glycaemic control, lipid profile, blood pressure and body weight status among diabetics in rural areas are unsatisfactory and should be controlled to prevent diabetes complications, including those of a microvascular and macrovascular nature, among these subjects. Appropriate intervention programs should be implemented for better diabetes control among these subjects.

\section{REFERENCES}

1. Zaini A. Where is Malaysia in the midst of the Asian epidemic of diabetes mellitus?. Diab Res Clin Pract 2000; 50:S23-S28

2. Ministry of Health Malaysia. National Health and Morbidity Survey 1996. Kuala Lumpur: Institute of Public Health, 1996

3. Osman A, Khalid BAK, Tan TT, Wu LL, Sakinah SO, $\mathrm{Ng}$ ML. Prevalence of NIDDM and impaired glucose tolerance in Aborigines and Malays in Malaysia and their relationship to sociodemographic, health and nutritional factors. Diabetes Care 1993; 16:68-74

4. Solano MP, Goldberg RB. Lipid Management in Type 2 Diabetes. Clin Diab 2006; 24:27-32

5. Turner R, Cull C, Holman R. UK Prospective Diabetes Study 17: a nine-year update of a randomized controlled trial on the effect of improved metabolic control on complications in non-insulin-dependent diabetes mellitus. Ann Intern Med 1996; 124:136-45

6. American Diabetes Association. Dyslipidemia Management in Adults with Diabetes. Diabetes Care 2004; 27:S68-S71

7. American Diabetes Association. Hypertension Management in Adults with Diabetes. Diabetes Care 2004; 27:565-567

8. International Diabetes Federation. Type 2 Diabetes Practical Targets and Treatments; The Asian Pacific Type 2 Diabetes Policy Group. Brussels: International Diabetes Federation, 2005.

9. Van der Does FE, De Neeling JN, Snoek FJ, et al. Symptoms and well-being in relation to glycemic control in type II diabetes. Diabetes Care 1996; 19:204-10

10. Ismail $M N$. The nutrition and health transition in Malaysia. Public Health Nutr 2002; 5:191-95

11. World Health Organization. The WHO STEPS wise approach to chronic disease risk factor surveillance. Geneva : World Health Organization 2006.

12. Mafauzy M. Diabetes control and complications in public hospitals in Malaysia. Med J Malaysia 2006; 61:477-83

13. World Health Organization. Physical Status: The Use and Interpretation of Antropometry. World Health Organization; 1995 WHO Technical Report Series no: 854.

14. National Institute of Health. Clinical Guidelines on the Identification, Evaluation, and Treatment of Overweight and Obesity in Adults. United States of America; National Institute of Health, 1998.

15. Friedewald WT, Levy RI, Fredrickson DS. Estimation of the concentration of low-density lipoprotein cholesterol in plasma, without use of the preparative ultracentrifuge. Clin Chem 1972; 18:499-502

16. The Diabetes Control and Complications Trial Research Group. The effect of intensive treatment of diabetes on the development and progression of long-term complications in insulindependent diabetes mellitus. New Engl J Med 1993; 329:977-86

17. Feldt-Rasmussen B, Mathiesen ER, Jensen T, Lauritzen T, Deckert T. Effect of improved metabolic control on loss of kidney function in type I (insulin-dependent) diabetic patients: an update of the Steno studies. Diabetologia 1991; 34: 164-70

18. The Kroc Collaborative Study Group. Diabetic retinopathy after two years of intensified insulin treatment. JAMA 1988; 260:37-41

19. Brinchmann-Hansen O, Dahl-Jørgensen K, Sandvik L, Hanssen KF. Blood glucose concentrations and progression of diabetic retinopathy: the seven year results of the Oslo study. Brit Med J 1992; 304:19-22

20. Eid M, Mafauzy M, Faridah AR. Dyslipidemic pattern of patients with type 2 diabetes mellitus. Malaysia J Med Sci 2004; 11:44-51

21. Suhaiza S, Ahmad Nasir M, Jeriah I, Abdul Aziz Al-Safi I, Wan Mohamad WB, Mafauzy M. Glycaemic Control among type 2 diabetic patients in Kelantan. NCD Malaysia 2004; 3:2-5

22. Mafauzy M. Diabetic control and complication in private health care in Malaysia. Med J Malaysia 2005; 60:212-17

23. The ADVANCE Collaborative Group. Intensive blood glucose control and vascular outcomes in patients with Type 2 diabetes. New Engl J Med 2008; 348:2560-72

24. Moss SE, Klein R, Klein BE, Meuer SM. The association of glycemia and cause-specific mortality in a diabetic population. Arch Intern Med 1994; 154:2473-79

25. Selvin E, Marinopoulos S, Berkenblit G, et al. Meta-analysis: glycosylated hemoglobin and cardiovascular disease in diabetes mellitus. Ann Intern Med 2004; 141:421-31

26. The DCCT Research Group. Lipid and lipoprotein levels in patients with IDDM diabetes control and complication trial experience. Diabetes Care 1992; 15:886-94

27. Petitti DB, Imperatore G, Palla SL, et al. Serum Lipids and Glucose Control: The SEARCH for Diabetes in Youth Study. Arch Pediatr Adolesc Med 2007; 161:159-65

28. Ismail IS, Nazaimoon W, Wan Mohamad WB. Ethnicity and glycaemic control are major determinants of diabetes dyslipidemia in Malaysia. Diabetes Med 2001; 18:501-08

29. Chuang LM, Tsai ST, Huang BY, Tai TY; DiabcareAsia 1998 Study Group. The status of diabetes control in Asia--a cross-sectional survey of 24,317 
patients with diabetes mellitus in 1998. Diabetes Med 2002; 19:978-85

30. Field AE, Coakley EH, Must A. Impact of over weight on the risk of developing common chronic diseases during a 10-year period. Arch Intern Med 2001; 161:1581-86

31. Visscher TL, Seidell JC. The public health impact of obesity. Annu Rev Public Health 2001; 22 :35575

32. Ford ES, Williamson DF, Liu S. Weight change and diabetes incidence: findings from a national cohort of US adults. Am J Epidemiol 1997; 146: 214-22

33. Golay A. Link between obesity and type 2 diabetes. Best Pract Res Clin Endocrinol Metab 2005; 19:649-63

34. Kahn SE, Hull RL \& Utzschneider KM. Mechanisms linking obesity to insulin resistance and type 2 diabetes. Nature 2006; 444:840-46 